ks. Andrzej Małachowski

Papieski Wydział Teologiczny we Wroctawiu

DOI: $10.15290 /$ std.2016.02.08

\title{
MAŁŻEŃSTWO JAKO COINCIDENTIA OPPOSITORUM - „A TAK JUŻ NIE SĄ DWOJE, LECZ JEDNO” (Mt 19, 6)
}

\section{MARRIAGE AS COINCIDENTIA OPPOSITORUM - "SO THEY ARE NO LONGER TWO, BUT ONE FLESH" $(M t 19,6)$}

In contemporary theological debate much attention is devoting to the interdisciplinary research. Theology as science based on philosophy. Today a special attention is to existential aspects of life. More an experience than the theological description or written reflection. However in order not to simplify theology, it is worthwhile leading and interpreting what religious studies above all widely understood and psychology are offering. The $20^{\text {th }}$ age is not only a new look at theology, inspired by the $2^{\text {nd }}$ Vatican Council but also an intense development of religious studies sciences, but first of all history of the religion with chief with its representative - Mircea Eliade.

With topic always current in all sciences, but first of all in theology and religious studies, there are a problem of the connection of the man and women. Two beings, two people and at the same time the great gap between them, two quite different worlds, and the one physical, bodily, and the one psychological, emotional as well as spiritual, religious. These two beings are two opposites which are pulling themselves one another, they are searching for themselves and they are uniting with themselves, and are becoming something with one thing. And so it is possible to look at the connection of the man and women in categories similarities of opposites, that is as coincidentia oppositorum. We will examine the dissimilarity of the man and the woman at first, next we will see what he is coincidentia oppositorum and how this principle is applying to 
the topic of the marriage as well as androgyne. We will look for justifying the principle in the last part coincidentia oppositorum in the biblical theology.

Key words: Mircea Eliade, marriage, coincindentia oppositorum, androgyne.

We współczesnej debacie teologicznej dużo uwagi poświęca się badaniom interdyscyplinarnym. Dziś w teologii zwraca się szczególną uwagę na aspekty egzystencjalne wynikające $z$ chrześcijańskiego personalizmu. Liczy się coraz bardziej przeżycie i świadectwo aniżeli opis teologiczny lub zapisana refleksja. Warto w teologii przyjrzeć się temu, co proponuje współczesne religioznawstwo, czy psychologia. Wiek XX to nie tylko nowe spojrzenie na teologie, inspirowane przez Sobór Watykański II, ale również intensywny rozwój nauk religioznawczych, a przede wszystkim historii i psychologii religii z głównym jej reprezentantem - Mirceą Eliade.

Dla teologii fundamentalnym zadaniem zawsze pozostanie odczytywanie Objawienia Bożego, zawartego w Piśmie Świętym i Tradycji oraz jego dostosowanie do współczesności poprzez subtelną interpretację. Dla religioznawstwa najważniejszą kategorią jest sacrum i profanum. Ludzkość od początków swego istnienia odczytywała objawiające się sacrum i tą prawdą żyła ${ }^{1}$. Współcześnie jednak stoi przed nowym problemem, profanizacją życia, teologią śmierci Boga, znikającym Absolutem, czy wyprowadzaniem religii ze świadomości do podświadomości. Ale jak pisze Mircea Eliade, religijność jest nieodłącznym elementem struktury świadomości człowieka i próba jej eliminacji może skończyć się utratą człowieczeństwa ${ }^{2}$. Analizując mity zauważa on, że w przekonaniu uformowanych przez nie ludzi „tylko sacrum jest par excellence rzeczywiste. To, co należy do sfery świeckiego, nie ma udziału w bycie, ponieważ nie zostało ontologicznie ustanowione przez mit i nie ma wzorcowego modelu" ${ }^{\text {" }}$. Dlatego wartość wszelkich poczynań ludzkich, takich jak zawierania małżeństwa czy życia małżeńsko-rodzinnego, nie wiąże się z ich czysto fizycznym aspektem, ale $z$ tym, że odtwarzają one jakiś mit pierwotny, że są powtórzeniem wzorca mitycznego. Człowiek kultury archaicznej odnajduje swoją rzeczywistość i tożsamość jedynie przez uczestniczenie w rzeczywistości transcendentnej, a to dokonuje się przez powtarzanie i naśladowanie archetypu niebiańskiego. Pełną rzeczywistość i tożsamość odnajduje on w czasie mitycznym i sakralnym, który jest czasem niezniszczalnej i wiecznej teraźniejszości. Właśnie powtarzając i naśladując archetyp niebiański - chce żyć w tym sakralnym czasie i w ten sposób być jak najbliżej bogów, a nawet uczestniczyć w ich „życiu”. We wszystkich

Por. A. Małachowski, Objawiające się sacrum, Wrocław 1999.

M. Eliade, Historia wierzeń $i$ idei religijnych, t. I, tł. S. Tokarski, Warszawa 1988, s. 1.

M. Eliade, Sacrum i profanum. O istocie religijności, tł. R. Reszke, Warszawa 1996, s. 78. 
epokach historycznych podstawą instytucjonalizacji małżeństwa i rodziny, która dokonuje się przez określone ceremonie i ryty (w chrześcijaństwie poprzez sakrament małżeństwa), jest ogólne przeświadczenie o powiązaniu małżeństwa i rodziny z czynnikiem nadprzyrodzonym, z sacrum, niezależnie od odmiennych w różnych religiach interpretacji tego czynnika, jako Boga osobowego, bóstw czy też pewnej siły nadprzyrodzonej, bądź duchów przodków4

Tematem zawsze aktualnym we wszystkich naukach, a przede wszystkim w teologii i religioznawstwie, jest problem związku mężczyzny i kobiety. Dwie istoty, dwoje ludzi, a jednocześnie wielka przepaść między nimi, dwa całkiem odmienne światy, i ten fizyczny, cielesny, i ten psychiczny, emocjonalny, a także duchowy, religijny. Te dwie istoty to dwa przeciwieństwa, które się przyciągają wzajemnie do siebie, szukają siebie i łączą się ze sobą, i stają się czymś jednym. A zatem można patrzeć na związek mężczyzny i kobiety w kategoriach zbieżności przeciwieństw, czyli jako coincidentia oppositorum. Nie jest to oczywiście możliwe w przypadku związku mężczyzny z mężczyzną albo kobiety z kobietą. Przyjrzymy się najpierw odmienności mężczyzny i kobiety, następnie zobaczymy czym jest coincidentia oppositorum i jak ta zasada stosuje się do tematu małżeństwa i androgynii. W ostatniej części poszukamy uzasadnienia zasady coincidentia oppositorum w teologii biblijnej.

\section{Mężczyzna i kobieta jako odmienności i przeciwieństwa ${ }^{5}$}

Mężczyźni i kobiety są sobie równi ze względu na wspólną przynależność do tego samego gatunku - homo sapiens. Mężczyźni są silni w dziedzinach, w których kobiety są słabe, a kobiety silne w tym, w czym słabi są mężczýni. Czy to tylko przewaga mężczyzn pod względem muskulatury i wagi ciała spowodowała, że świat kobiet był przez parę tysięcy lat terytorium okupowanym? Czy też fakt, że jeszcze parę wieków temu kobiety przez większą część swego życia były w ciąży?

Pierwsze systematyczne testy badające różnice między płciami przeprowadzone zostały w roku 1882 w Londynie. Istnieją znaczące różnice dające mężczyznom pierwszeństwo pod względem siły chwytu, wrażliwości na ostre, świszczące dźwięki i zdolności do pracy w warunkach stresu, a kobiety są bardziej wrażliwe na ból. Kobiety słyszą lepiej niż mężczyźni, mają bardziej

\footnotetext{
$4 \quad$ F. Adamski, Rodzina między sacrum a profanum, Poznań 1987, s. 9.

5 Ta część została opracowana na podstawie książki A. Moir, D. Jessel, Pteć mózgu. O prawdziwej różnicy między mężczyzną a kobieta, tł. N. Kancewicz-Hoffman, Warszawa 1993, s. 17-33, 140-159, 178-199. E. Głażewska, Androgynia-model człowieka XXI wieku, „Annales Universitatis Mariae Curie-Skłodowska”, Lublin - Polonia, t. XXVI, 2, 2001, s. $17-28$.
} 
konwencjonalne słownictwo i wolą kolor niebieski od czerwonego. Mężczyźni przedkładają czerwony nad niebieski, mają swobodniejsze słownictwo. Preferują także myślenie bardziej abstrakcyjne i ogólne, podczas gdy kobiety wolą problemy praktyczne i konkretne zadania.

Znajdujemy przewagę kobiet nad mężczyznami pod względem pamięci, sprytu, umiejętności udawania, zdolności do współczucia, cierpliwości i schludności. Prace kobiet naukowców są dokładniejsze niż prace mężczyzn, ale czasami brakuje im szerokości spojrzenia i samodzielności. Kobiecy geniusz wydawał się potrzebować wsparcia mężczyzny ${ }^{6}$. Kobiety nie lubią intelektualnego w swej istocie procesu analizy. Czują instynktownie, że analiza mogłaby zniszczyć sferę emocji, która najczęściej powoduje ich czynami i która najbardziej do nich przemawia.

Łatwo jest zauważyć, że mężczyźni są wyżsi od kobiet. Oczywiście, niektóre kobiety okażą się wyższe niż mężczyźni, ale statystycznie mężczyźni są przeciętnie o 7\% wyżsi. Statystyczna zmienność różnic między kobietą a mężczyzną, różnic w umiejętnościach, uzdolnieniach i możliwościach, jest dużo większa niż zróżnicowanie pod względem wzrostu. Zawsze będą wyjątki od przeciętnej, ale nie unieważniają one ogólnej, statystycznej zasady. Różnice średnich wyników obu płci mierzone za pomocą rozmaitych testów uzdolnień mogą osiągać nawet $25 \%$.

Największe różnice są w tym, co psycholodzy nazywają „wyobraźnią przestrzenną". Jest to zdolność do wizualizowania w wyobraźni przedmiotów, ich kształtu, położenia, rozmieszczenia i proporcji - wszystkie te umiejętności stanowią podstawę praktycznej zdolności do pracy z przedmiotami trójwymiarowymi lub rysunkami. Tylko jedna czwarta kobiet umie wykonać to zadanie lepiej niż przeciętny mężczyzna. Na szczycie tej skali zdolności technicznych znajduje się dwa razy tyle mężczyzn co kobiet.

Poczynając od wieku szkolnego, chłopcy zazwyczaj prześcigają dziewczęta w dziedzinach matematyki wprowadzających takie pojęcia abstrakcyjne jak „przestrzeń” „teoria” i „zależności”. Na każdą wyjątkowo uzdolnioną dziewczynkę przypada ponad trzynastu równie uzdolnionych chłopców?

Chłopcy mają także lepszą koordynację ręka - oko, konieczną w grach w piłkę. Jednocześnie te właśnie zdolności oznaczają, że mogą oni z większą łatwością przedstawić sobie, przekształcić i obrócić przedmiot w wyobraźni. Chłopcom łatwiej jest zbudować z klocków budynek na podstawie dwuwymiarowych projektów. Większe zdolności przestrzenne mężczyzn mogą z pewnością pomóc

Por. B. Goldsmith, Geniusz i obsesja. Wewnętrzny świat Marii Curie, Wrocław 2006.

7 Na ten temat: A. Małachowski, Kobiety w matematyce, [w:] Żyjemy dla Pana: księga pamiątkowa dedykowana S. Profesor Ewie Józefie Jezierskiej OSU w siedemdziesiąta rocznicę urodzin, M. Rosik (red.), Wrocław 2005, s. 377-393. 
w wyjaśnieniu przewagi mężczyzn w czytaniu mapy. Chłopcom i dziewczętom dawano plan miasta i proszono o określenie - bez obracania planu - czy będą skręcać w prawo, czy w lewo na wskazanych skrzyżowaniach podczas przejazdu przez miasto w wyobraźni. Chłopcy mieli lepsze wyniki.

Podczas gdy mózg mężczyzny daje mu przewagę w radzeniu sobie z przedmiotami i twierdzeniami teoretycznymi, mózg kobiety jest tak zorganizowany, że lepiej reaguje na wszystkie bodźce zmysłowe. Kobiety wypadają lepiej we wszystkich testach sprawności werbalnej. Są też przystosowane do otrzymywania szerszego zakresu informacji zmysłowych, do łatwiejszego łączenia tych informacji ze sobą i dostrzegania relacji między nimi, do kładzenia nacisku na relacje między ludźmi i na procesy komunikacji.

Dziewczynki wcześniej niż chłopcy wypowiadają pierwsze słowa i potrafią mówić krótkimi zdaniami, z reguły też mówią z większą łatwością. Wcześniej zaczynają czytać i lepiej sobie radzą z takimi elementami języka jak gramatyka, interpunkcja i ortografia. Później kobiety z większą łatwością uczą się języków obcych. Mówią również z większą płynnością - jąkanie i inne wady wymowy występują niemal wyłącznie u chłopców.

Kobiety słyszą lepiej niż mężczyźni. Wykazują większą wrażliwość na dźwięk. Kapiący kran wyciągnie kobietę z łóźka, zanim mężczyzna zdoła się obudzić. Sześć razy więcej dziewcząt niż chłopców umie śpiewać. Lepiej też dostrzegają małe zmiany natężenia głosu, co może stanowić częściowe wyjaśnienie niezwykłej wrażliwości kobiet na „ten ton”, o którego używanie tak często oskarżają swoich partnerów.

Kobiety i mężczyźni widzą świat inaczej. Kobiety, lepiej od mężczyzn widzą w nocy. Są bardziej wrażliwe na czerwony kraniec spektrum barw światła i odróżniają więcej odcieni czerwonego niż mężczyźni. Mają lepszą pamięć wzrokową. Mężczyźni widzą lepiej niż kobiety w jasnym świetle. Mężczyźni mają skłonność do - dosłownie - klapek na oczach: ich pole widzenia jest stosunkowo wąskie przy większej koncentracji na głębi widzenia. Mają lepsze wyczucie perspektywy niż kobiety. Kobiety natomiast całkiem dosłownie odbierają większy obraz. Mają szersze widzenie obwodowe, bo występuje u nich więcej światłoczułych pręcików i czopków w siatkówce z tyłu gałki ocznej, co powoduje, że otrzymują obraz z szerszego pola widzenia.

Kobiety szybciej i dotkliwiej reagują na ból, choć ich ogólna odporność na długotrwałe cierpienia jest większa niż mężczyzn. Kobiety odznaczają się taką przewagą pod względem wrażliwości dotykowej nad mężczyznami, najmniej wrażliwa kobieta okazuje się wrażliwsza niż najbardziej wrażliwy mężczyzna.

Mężczyźni i kobiety mają odmienne zmysły smaku - kobiety są bardziej wrażliwe na smaki gorzkie, a słodycze wolą bardziej skondensowane i w większych ilościach. Mężczyźni osiągają lepsze wyniki w rozróżnianiu smaków słonych. 
Nie tylko podniebienia, ale i nosy kobiet są wrażliwsze niż mężczyzn. Dobrym tego przykładem jest reakcja kobiet na woń właściwą mężczyznom, ale dla nich samych niemal niezauważalną.

Tę przewagę kobiet pod względem wrażliwości wielu zmysłów można zmierzyć w badaniach klinicznych - i to właśnie ona tłumaczy niemal nadnaturalną „intuicję" kobiet. Są one po prostu lepiej wyposażone do spostrzegania zjawisk, na które mężczyźni w porównaniu z nimi są ślepi i głusi. W tych niezwykłych zdolnościach percepcyjnych są one pozazmysłowe w porównaniu z przytępionymi zmysłami męskimi. Kobiety lepiej wychwytują sygnały społeczne, odbierają istotne subtelności znaczeń na podstawie tonu głosu albo intensywności wyrazu. Mężczyźni są czasem rozgoryczeni reakcją kobiety na to, co powiedzieli. Nie zdają sobie sprawy, że kobieta "słyszy” prawdopodobnie o wiele więcej, niż mężczyzna w swoim przekonaniu „mówi”. Kobiety lepiej zazwyczaj umieją ocenić charakter. Kobiety mają lepszą pamięć do nazwisk i twarzy oraz dat, a także większe wyczulenie na preferencje innych ludzi.

Stwierdzono także różnice pod względem pamięci między kobietami i mężczyznami. Kobiety mogą zmagazynować, przynajmniej na krótki czas, więcej informacji nieistotnych i przypadkowych niż mężczyźni. Mężczyznom udaje się to tylko wtedy, gdy informacja tworzy jakąś spójną formę albo ma dla nich pewne konkretne znaczenie.

Mężczyzna i kobieta myślą na różny sposób, różne są ich mocne strony, różne skale wartości, różne strategie wobec życia. Kobieta jest z samej swej istoty bardziej wrażliwa niż mężczyzna. Reaguje silniej na dotyk, zapach i dźwięk. Więcej widzi i bardziej szczegółowo pamięta to, co widzi. Przywiązuje większą wagę do tego, co wiąże się z życiem osobistym i z kontaktami między ludźmi. Od samego początku bardziej interesuje się ludźmi. Lepsza jest w nadawaniu i odbieraniu sygnałów społecznych zapisanych w języku ciała. Częściej niż mężczyźni śmieje się, kiedy nie jest szczęśliwa, i częściej od nich jest miła dla ludzi, których nie lubi - możliwe, że jest to mechanizm obronny rekompensujący jej słabość fizyczną w porównaniu z mężczyznami. Utrzymuje bliższe, dłuższe i bardziej regularne kontakty z przyjaciółmi, którym powierza więcej ze swych nadziei i lęków. Ma lepszą pamięć do twarzy i charakterów. Lepiej niż mężczyzna rozumie, o co chodzi kobiecie lub mężczýnie, nawet kiedy pozornie ona lub on nic nie komunikują. Jej prawa półkula mózgowa, kontrolująca emocje, jest lepiej niż u mężczyzn połączona z półkulą lewą, kontrolującą ekspresję słowną. Innymi słowy, intuicja jest u niej w lepszym kontakcie z umiejętnościami komunikacyjnymi.

Mężczyzna oddaje się tymczasem zupełnie innym sprawom. W zakresie podstawowych zmysłów mężczyzna słyszy i czuje mniej. Skupia się bardziej na poszczególnych sprawach, bo jego umysł jest w większym stopniu 
poszufladkowany. Nie dostrzega czynników rozpraszających. Jego świat - to świat przedmiotów - czym są, jak działają, jaką zajmują przestrzeń.

Te dwie obce sobie istoty rzucają się sobie w ramiona za sprawą biologii, która powoduje, że są dla siebie pociągający fizycznie, choć jednocześnie przeciwstawni pod tyloma innymi względami. Gdyby płcie rozumiały się nieco lepiej-drogi prawdziwej miłości byłyby nieco mniej wyboiste. Kochamy nasze odmienności fizyczne, ale odmienności charakteru, umysłu, wartości i wrażliwości możemy pokochać dopiero wówczas, kiedy je rzeczywiście poznamy i zrozumiemy.

Mężczyzna ze złamanym sercem mówi, jak bardzo mu jej braknie i jak jej potrzebuje; kobieta, niestety, wie, że brak i potrzeba nie stanowią podstawy do związku między ludźmi. W mózgu kobiety ośrodki rozsądku i emocji są fizycznie lepiej połączone. Kobieta lepiej jest wyposażona do analizowania i racjonalizowania. Młodzi mężczyźni zakochują się częściej niż kobiety. Ona szczerze chce, aby on wyraził swoje uczucia i myśli, podzielił się swoimi nadziejami i obawami. On chciałby, aby ona dała mu święty spokój. To znana męska postawa: „Zawsze mówi, że z nią nie rozmawiam. Nie rozumiem tego. Jestem pewien, że wie, co myślę, ale to jej nie wystarczy". Podczas gdy z kobiecego punktu widzenia: „On czasami słucha, ale rzadko kiedy zdarza się, żeby odpowiedział. Trudno rozmawia się z pijakiem, a jednak jest to jedyna sytuacja, w której okazuje mi jakiekolwiek prawdziwe uczucia”. Alkohol przełamuje bariery między odrębnymi szufladkami męskiego mózgu. Inny mężczyzna, gdy go poproszono, by okazał swojej partnerce więcej uczucia, umył jej samochód. I znów ujawnia się tutaj nieporadność męskiego języka miłości, który sprowadza się do robienia czegoś, do wspólnych zajęć. Mężczyźni okazują swą miłość przez zaproszenie na kolację, żaglówkę, narty, a nawet na mecz piłki nożnej. Przyjaźń kobiet opiera się na dzieleniu się zwierzeniami. Z kolei mężczyźni powinni w większym stopniu zaakceptować potrzebę komunikacji w związku z kobietą. Nie przyjdzie im to łatwo, bo język uczuć jest im obcy i wyrażają się nieco niezgrabnie. Ale jako sposób wyznania miłości lepsze to niż umycie jej samochodu.

Kobieta wnosi do związku wrażliwość emocjonalną, skłonność do wzajemnej współzależności, tęsknotę za bliskością uczuciową i za seksem jako wyrazem tej emocjonalnej intymności. Mężczyzna jest w dziedzinie uczuć znacznie mniej wymagający, a bywa nawet zupełnie ślepy na ich wagę. Skłonny jest do niezależności i swoje obowiązki w ramach kontraktu małżeńskiego postrzega przede wszystkim w kategoriach zapewnienia bezpieczeństwa finansowego. Mężczyzna prawdopodobnie nie wie, że biologia kobiety spowoduje u niej niezrozumiałe i nieracjonalne zmiany nastroju. Ona nie zdaje sobie sprawy, że jego biologia niesie $z$ sobą niższy próg gniewu i frustracji. Problem ujawnia się w odpowiedziach 95\% respondentek twierdzących, że cierpią z powodu „emocjonalnego i psychologicznego znęcania się”, 98\% sfrustrowanych brakiem 
„werbalnej bliskości” z partnerem, 79\% wątpiących, czy nadal powinny wkładać tak wiele energii w związek miłosny i 87\% przyznających, że najgłębszy związek emocjonalny łączy je $z$ inną kobietą.

Brak porozumienia to jedno z podstawowych zjawisk w życiu. Wydaje się absolutnie przewidywalne, że kobiety zadręczać się będą niekomunikatywnością mężczyzn - bo przecież mózgi mężczyzn nie są przystosowane do tego celu. Wydaje się nam zupełnie naturalne, że najbliższym przyjacielem większości kobiet jest inna kobieta, bo biologia kobiety ogromne znaczenie nadaje związkom między ludźmi. Mężczyźni chcą w związku objąć rolę "gwiazdy” i najważniejszą sprawą jest dla nich „być”, podczas gdy dla kobiety - „dawać”.

Kobiety zaczęły akceptować swoją seksualność, a jeśli chodzi o równość, to rozumiały, że władza może mieć rozmaite postacie. Dla mężczyzn wyraża się ona tradycyjnie w dominacji i agresji - na tych pojęciach opiera się męska definicja pozycji społecznej. Władza kobiet polega na czymś subtelniejszym. To siła, która tworzy związki między ludźmi, spaja rodziny i buduje społeczeństwa. Kobiety, które to rozumieją, które nie negują wartości i siły tej nieodłącznej, nieocenionej, zasadniczej zalety swojej płci, mniej mają niepokojów związanych ze swoją pozycją. Nie należy przez to rozumieć, że kobiety te akceptują uprzedzenia, z jakimi często spotykają się w domu czy w pracy, ale zdają one sobie sprawę z tego, że mają pewne umiejętności, których brak mężczyznom.

W badaniach poproszono kobiety i mężczyzn o opisanie, ,jakim człowiekiem najbardziej chciałbym/chciałabym być”. Wśród cech wybieranych najczęściej przez mężczyzn były praktyczność, bystrość, pewność siebie, skłonność do dominacji i rywalizacji, krytycyzm i samokontrola. Kobiety częściej opisywały swój ideał jako osobę kochającą, czułą, impulsywną, współczującą i wielkoduszną. W innych badaniach poproszono o ocenę różnych zainteresowań i zajęć, dziewczęta wyżej stawiały wartości społeczne, estetyczne i religijne, podczas gdy chłopcy preferowali wartości ekonomiczne, polityczne i teoretyczne. Kobiety ceniły „interesujące doświadczenia” albo „służbę społeczeństwu”, natomiast mężczyźni najwyżej stawiali władzę, korzyść i niezależność. Mężczyźni cenią sobie konkurencję, nowinki naukowe i zasady, prestiż, władzę, dominację i wolność, podczas gdy kobiety cenią więzi między ludźmi i bezpieczeństwo.

Kobiety wykazują większą od mężczyzn wrażliwość na bodźce emocjonalne. Są też z natury troskliwsze, co przejawiały już jako dziewczynki ciepło witając nowego uczestnika zabaw. Wydaje się, że pojmowanie prawości jest u kobiet ściśle powiązane $z$ etyką troski, toteż myśląc o sobie jako o kobietach, myślą o sobie w związkach z innymi ludźmi.

Największym poza seksem zagrożeniem małżeństwa jest nierówność kontraktu w sferze uczuć. 98\% kobiet chce, aby mężczyźni więcej z nimi rozmawiali o swoich osobistych przemyśleniach, wrażeniach, planach, emocjach, 
wątpliwościach - i żeby je pytali o to samo. $81 \%$ kobiet twierdzi, że to one inicjują większość poważnych rozmów, wkładając wiele wysiłku w skłonienie mężczyzn do wyrażania ich najskrytszych myśli i uczuć. Ale większość żon napotyka silny opór, kiedy starają się zmusić małżonka do rozmowy o uczuciach. Dochodzą one do wniosku, że ich partnerzy obawiają się wyrażania uczuć. Blisko trzy czwarte kobiet zrezygnowało w końcu z osiągnięcia bliskich związków emocjonalnych z partnerem. Większość twierdzi, że mężczyzna często nie słucha naprawdę, że często zaleca im nie odczuwać tego, co odczuwają, albo przynajmniej tego nie ujawniać.

Kobiety są bardziej emocjonalne, ponieważ specjalnie zostały tak ukształtowane, by troszczyły się o ludzi. Odczuwają cierpienie innych jak swoje własne. Mężczyźni, nastawieni na działanie, na cierpienie drugiego człowieka odpowiadają poszukiwaniem dla niego praktycznego rozwiązania. Płacz dziecka trafia wprost do serca matki. Ojciec idzie po książkę o opiece nad niemowlęciem, by przeszukać katalog możliwych przyczyn i środków zaradczych. Mężczyźni często wyrażają swoją opiekuńczość bawiąc się z dziećmi.

Połączenia nerwowe w męskim mózgu zaprogramowane są bardziej do działania niż do zainteresowania ludźmi. Mózg mężczyzny ignoruje całe megabajty informacji o ludziach, zawarte w subtelnych sygnałach wizualnych, na które kobiety reagują w rozmowie ze znacznie większą łatwością. Mężczyzna musi np. zapytać: „Czy cię nudzę?” Kobieta to wie. Męski sposób postrzegania daje mężczyźnie mniej informacji do dalszego działania. Mężczyźni uważają, że łatwiej dać sobie radę z rzeczami niż z ludźmi: samochód staje - zatkał się gaźnik. Przenosi on tę postawę na sferę spraw międzyludzkich: niemowlę płacze - trzeba mu zmienić pieluchę. Mężczyzna nie może zrozumieć, dlaczego kobieta tak wiele czasu spędza zadręczając się ich związkiem. Tak samo jak ona nie może pojąć, dlaczego on spędza tyle czasu dłubiąc przy samochodzie.

Kobiety rzadko rozumieją inną jeszcze przyczynę tej ucieczki mężczyzn od bliskości. Mężczyźni po prostu potrzebują więcej „przestrzeni” - w każdym sensie. To jest jego terytorium, miejsce, o którym wiadomo, że ma tam prawo przebywać, rozmyślać, palić lub czynić cokolwiek innego - samotnie. To nieprzypadkowy zbieg okoliczności, że ulubiona rozrywka mężczyzn - chodzenie na ryby - wiąże się z samotnością, przestrzenią i wolnością od wszelkich kontaktów z ludźmi. Jedno z wyjaśnień tej męskiej potrzeby większej przestrzeni odwołuje się do męskiej potrzeby dominacji - przestrzeń jako symbol statusu. Bardziej prawdopodobne jest jednak, że męski mózg nie jest przystosowany do intymności, przed którą mężczyzna fizycznie się wzdraga. Natomiast mózg kobiety jest do tego przystosowany, czego odzwierciedleniem jest jej pragnienie bliskości.

Kobiety widzą, słyszą i odczuwają więcej i to więcej dla nich znaczy. Również płaczą częściej niż mężczyźni, może dlatego, że mają więcej powodów do płaczu 
- dociera do nich więcej sygnałów emocjonalnych, mocniej na nie reagują i wyrażają to z większą siłą. Być może mężczyzna nie dlatego płacze mniej, że nauczono go nie okazywać w takim stopniu swoich uczuć, tylko dlatego, że w gruncie rzeczy nie dostrzega krzywdy czy obrazy tak jak kobieta. Mniej to dla niego znaczy.

Jeśli mężczyzna naprawdę płacze, musi mieć po temu jakiś istotny i ważny powód, podczas gdy kobiecy wyraz uczuć, czy to fizyczny, czy werbalny, często odznacza się pewną przesadą. Kobiety z kolei traktują te męskie odpowiedzi jako sarkastyczne „oblanie zimną wodą”, co doprowadza je do szału. W rzeczywistości jest to nieporadna reakcja na dzielącą ich otchłań percepcji i komunikacji. Dlaczego ona nie sprowadzi rzeczy do właściwej skali? Ponieważ jej pojęcie właściwej skali jest inne niż jego. Jego jest dosłowne i obiektywne. Jej jest przybliżone i subiektywne.

Ale czy te cechy nie są sprzeczne z ową specyficznie męską irracjonalnością, $z$ łatwością popadania $w$ gniew? Podobnie jak łatwiej jest pobudzić seksualnie mężczyznę niż kobietę, tak samo łatwiej pobudzić w nim frustrację i złość. I, podobnie jak z namiętnością, daje on tej złości szybko upust w formie wybuchu. Gniew odzwierciedla też inną jeszcze skłonność męskiego umysłu. Przejawianie gniewu wymaga pewnej depersonalizacji obiektu naszej wściekłości - w gruncie rzeczy osoba taka staje się „przedmiotem” i wskutek tego bardziej odpowiada nastawieniu męskiego umysłu. Gniew i przemoc wymagają bardziej abstrakcyjnego, bezosobowego spojrzenia na świat - inni ludzie stają się wówczas rzeczami, na które można krzyczeć i wrzeszczeć.

Kobiety są ekspertami w dziedzinie polityki małżeńskiej i więzi społecznych. Ich umiejętności dyplomatyczne i społeczne dają im decydującą przewagę w dążeniu do utrzymania tej nienaturalnej - dla mężczyzn - instytucji. Większa wrażliwość kobiet na niewerbalne sygnały behawioralne sprawia, że uważniej obserwują twarze i mają lepszą pamięć do twarzy. Władza, w każdym państwie, zależy od posiadania informacji. W państwie małżeńskim kobiety mają jej więcej.

Zdradzający żonę mężczyzna jest zaskoczony, jak to się dzieje, że jego żona zdaje się ,intuicyjnie” wiedzieć, co się z nim dzieje. Kobiety po prostu więcej dostrzegają. I nie chodzi tu ani o ów blond włos, ani o to, że mężczyzna zwraca więcej niż zwykle uwagi na swoją higienę osobistą, choć mężczyzna nigdy by nie odebrał takich sygnałów od kobiety. Kobieta widzi z zachowania mężczyzny, $z$ tego, jak on wygląda, mówi i stoi, że coś się dzieje. Mężowie są dla swoich żon otwartą księgą dzięki właściwej kobietom większej bystrości w postrzeganiu. Mężczýni często nie zdają sobie sprawy, co kobiety dostrzegają.

Małżeństwa trwają, ponieważ wrodzone uzdolnienia społeczne kobiet - nazywa się je „inteligencją społeczną” - pozwalają im kierować związkiem znacznie 
lepiej niż mężczyznom. Kobiety lepiej niż mężczyźni potrafią przewidzieć i zrozumieć zachowania ludzkie, wyczuć motywy kryjące się za wypowiedzią czy zachowaniem.

\section{Zasada zbieżności przeciwieństw (coincidentia oppositorum)}

Pojęcie coincidentia oppositorum zostało po raz pierwszy sformułowane przez Mikołaja z Kuzy (1401-1464). Jednak już wcześniej stanowiło problem dla filozofów starożytnej Grecji. Wielość bytów nakazywała postawić pytanie: skąd pochodzi wielość, dlaczego istnieją przeciwieństwa? Twierdzono, że wyłoniła się ona $z$ bezkształtnego, rozmaicie pojmowanego chaosu, z którego powstały, gdy jakaś tajemnicza siła czy zasada wywarła nań swój kształtujący wpływ ${ }^{8}$.

Zagadnienie to było obecne filozofii od Talesa (VII-VI w. przed Chr.), poprzez Platona (427-347 p. Chr.) do Plotyna (204-270) i Proklosa (412-485). Znajdujemy je w „bezkresie” Anaksymandra (611-546 przed Chr.), w stwierdzeniu Heraklita (550-475 przed Chr.), że Bóg jest dniem i nocą, zimą i latem, wojną i pokojem, sytością i głodem, jest wszystkimi tymi przeciwieństwami, w ,Jedności” pitagorejczyków9 ${ }^{9}$. Wszędzie ujawniał się problem relacji między „jednością” i jej przeciwieństwem - „wielością”. Dla Pseudo-Dionizego Areopagity (V-VI w.) zbieżność przeciwieństw w Bogu stanowiła tajemnicę.

Wyrażenie „zbieżność przeciwieństw”, to współistnienie przeciwieństw, ich łączenie, schodzenie się, zespolenie, zjednoczenie, albo ich reintegracja. Używa się też łacińskich określeń: coincidentia oppositorum, complexio oppositorum, misterium coniunctionis.

Problem zbieżności przeciwieństw podjął Mikołaj z Kuzy, w dziele De docta ignorantia. Inspiracją dla stworzenia zasady, którą nazwał coincidentia oppositorum, była koncepcja Boga u Pseudo-Dionizego Areopagity, a mianowicie, że Absolut jako Jedność łączy w sobie wielość oraz jest doskonałością wszystkich istot. Zatem jeżeli świat pochodzi od Boga, to Bóg musi być w jakimś sensie zespoleniem wielości rzeczy. Zasadę coincidentia oppositorum przedstawił Mikołaj z Kuzy w dziele De docta ignorantia: „Tak tedy widzimy, że ponad wszelkim dyskursem rozumu leży w sposób niepojęty absolutne i nieskończone Największe, któremu nie przeciwstawia się nic, z którym zbiega się Minimum. «Maksimum»

8 Por. M. Eliade, Mefistofeles i androgyn, tł. B. Kupis, Warszawa 1994, s. 83-86.

9 Tablica z dziesięciu par przeciwieństw w filozofii pitagorejczyków to: 1. ograniczony nieograniczony, 2. parzysty - nieparzysty, 3. jedność - wielość, 4. prawy - lewy, 5. męski -żeński, 6. dobry - zły, 7. światło - ciemność, 8. kwadratowy - podłużny, 9. prosty - krzywy, 10. ruch - spoczynek. Chrześcijaństwo dodało jeszcze trzy nowe pary przeciwieństw: 1. świat doczesny - świat wieczny, 2. śmierć - życie, 3. poznanie cząstkowe - poznanie pełne. 
więc $i$ «Minimum», [...] okazują się transcedentalnymi terminami o absolutnym znaczeniu, aby w swej absolutnej prostocie, ponad wszelką redukcją do ilości masy czy siły, mieściły w sobie wszystko" ${ }^{10}$. Ponieważ nie może być proporcji między skończonym a nieskończonym (tzw. Aksjomat Kuzańczyka) stąd każde ludzkie poznanie jest względne, złożone i skończone nie może uchwycić prawdy, która jest prosta i nieskończona. Skoro prawda, absolutne maximum, przewyższa rozum niezdolny do rozwikłania sprzeczności, to należy wyjść poza rozum, jak również poza wyobraźnię, i ująć maximum za pośrednictwem intuicji. Intelekt może przezwyciężyć różnice i różnorodności, ale nie może tego wyrazić w języku racjonalnym. Bóg stanowi połączenie tego, co nieskończenie wielkie, z tym, co nieskończenie małe. Bóg nie jest ani jednym, ani trójjedynym, lecz jednością, która łączy się z Trójcą. Bóg w swej nieskończonej prostocie obejmuje (complicatio) wszystkie rzeczy, ale jednocześnie jest obecny we wszystkich rzeczach (explicatio $)^{11}$. Zjednoczenie wszystkich przeciwieństw dokonuje się w Bogu. Oznacza to, iż pojęcie coincidentia oppositorum jest swoistą, prostą i najmniej niedoskonałą definicją Boga.

Coincidentia oppositorum jest jednym z najstarszych sposobów wyrażania paradoksu pełni rzeczywistości Boskiej ${ }^{12}$. Stanowi ona wzór, który można odnaleźć w każdej formie doświadczenia religijnego. Nie może być inaczej skoro, jak twierdzi Eliade: „Właściwie każda hierofania, nawet najbardziej elementarna, ujawnia ową paradoksalną zbieżność sacrum i profanum, bytu i niebytu, tego, co absolutne, i tego, co względne, wieczności i stawania się"13. Człowiek, od początku swego kulturowego istnienia daje wyraz fascynacji tajemnicą Pełni. Od najdawniejszych czasów doświadczamy w niej objawienia tego, co rzeczywiste. Sacrum daje się poznać jedynie „w” i „poprzez” elementy świata profanum, bo ono - „ma granice nieskończone” ${ }^{14}$.

Mircea Eliade przyjmuje ideę zbieżności przeciwieństw od Kuzańczyka i stosuje ją do człowieka. Poniekąd ma do tego prawo, bowiem człowiek - mężczyzna i kobieta - jest „na obraz i podobieństwo Boże” ( $\operatorname{Rdz} 1,26-27)$. Co więcej, zgodnie z nauką Mikołaja z Kuzy, człowiek jest „mikrotheos”. Nie podejmuje tego tematu w teologii, lecz szeroko rozwija na obszarze historii religii. Twierdzi,

$10 \quad$ Mikołaj z Kuzy, O oświeconej niewiedzy, Kraków 1997, s. 53.

11 M. Eliade, Historia wierzeń $i$ idei religijnych. Od Mahometa do wieku reform, t. III, tt. A. Kuryś, Warszawa 2008, s. 188.

12 Por. M. Eliade, Traktat o historii religii, tł. J. Wierusz Kowalski, Warszawa 2000, s. 441.

13 Ibidem, s. 45.

14 A. Rega, Człowiek w świecie symboli. Antropologia filozoficzna Mircei Eliadego, Kraków 2001, s. 116. 
iż choć realizacja coincidentia oppositorum może przybierać rożne formy ${ }^{15}$, to jednak cel pozostaje ten sam: odtworzyć w sobie jedność pierwotną, taką, jaka panowała przed aktem stwórczym. Jedność pierwotną rozumie Eliade jako niezróżnicowany byt, który obejmuje wszystkie formy ${ }^{16}$. W swoim zapiskach z 8 stycznia 1979 roku pisze: „Problem zbieżności przeciwieństw będzie mnie fascynowal po kres moich dni"17.

Rozbicie pierwotnej jedności można postrzegać w dwóch wymiarach, którym odpowiadają dwa odmienne typy polaryzacji: 1) polaryzacje kosmiczne - wśród kosmicznych przeciwieństw można wyróżnić polaryzacje o strukturze przestrzennej (prawa - lewa, wysoki - niski i inne), o strukturze czasowej (dzień noc, pory roku i inne), oraz te, które wyrażają proces życia kosmicznego (życie - śmierć, rytmy wegetacji i inne) oraz 2) polaryzacje związane bezpośrednio $z$ kondycją człowieka - jest ich więcej niż w przypadku polaryzacji kosmicznych. Najważniejszą jest para mężczyzna-kobieta, stąd tak wielkie znaczenie mitu androgynii. Ponadto istnieją dychotomie etniczne (my - obcy), religijne (sacrum - profanum), etyczne (dobro - zło), mitologiczne (niebo - piekło).

Mircea Eliade uważa, iż wiele $z$ wymienionych dychotomii przynależących do różnych grup implikuje się wzajemnie (góra - dół; niebo - piekło). Tak skonstruowane pary przeciwieństw pozwalały człowiekowi odsłonić zarówno struktury uniwersum, jak również znaczenie jego własnej egzystencji ${ }^{18}$. Relacje między przeciwieństwami bywają bardzo różnorodne. Mogą się one wzajemnie zwalczać, albo łączyć się ze sobą (np. człowiek, który, jak twierdził Pascal, zawieszony jest między „tym, co nieskończenie wielkie i dobre” a „tym, co nieskończenie małe i złe”), bądź też współistnieć ze sobą, połączone w paradoksalnym związku określonym przez Kuzańczyka mianem coincidentia oppositorum ${ }^{19}$.

Niestety nie wszystkie realizacje formuły coincidentia oppositorum prowadzą do osiągnięcia tego samego sposobu istnienia. O ile orgia stanowi o powrocie do chaosu - stanu pierwotnego niezróżnicowania, o tyle techniki kontemplacyjne, choć również prowadzą do początku, to jednak stosujący je człowiek

15 Coincidentia oppositorum czy też transcendencja wszelkich przymiotów może być zrealizowana przez człowieka na różne sposoby. Na przykład „orgia” przedstawia ją na najniższym, najbardziej elementarnym stopniu życia religijnego; czyż nie jest ona symbolem regresji do tego, co bezkształtne i niewyraźne, oraz próbą odzyskania stanu, w którym się znoszą wszystkie przymioty, a przeciwieństwa się przyciągają? M. Eliade, Traktat o historii religii, op. cit., s. 441.

16 Ibidem.

17 Idem, Moje życie. Fragmenty dziennika 1941-1985, tł. I. Kania, Warszawa 2001, s. 1034.

18 Por. M. Eliade, W poszukiwaniu historii i znaczenia religii, tł. A. Grzybek, Warszawa 1997, s. 235-236.

$19 \quad$ A. Rega, Człowiek w świecie symboli..., op. cit., s. 117. 
uzyskuje stan określany terminem „wyzwolony za życia” - odzyskuje on „sytuację pierwotną" wzbogaconą jednak o element wolności i świadomości transcendentnej ${ }^{20}$.

Według M. Eliadego pojęcie coincidentia oppositorum stało się wzorem dla niektórych osób dążących do zdobycia doskonałego (pełnego) sposobu istnienia. Wszelkie mity i symbole, ryty i techniki kontemplacyjne odwołujące się do zjednoczenia przeciwieństw, wskazują nade wszystko na niezadowolenie człowieka z sytuacji, w której żyje, z tego, co się nazywa jego uwarunkowaniem ${ }^{21}$. Zjednoczenie przeciwieństw jest wyrazem nostalgii człowieka za pierwotną całością poprzedzającą wszelki akt stworzenia.

Rozważania M. Eliadego poświęcone zbieżności przeciwieństw wskazują, iż człowiek współczesny, dzięki docenianiu wartości poznawczej i emocjonalnej oraz różnie wyrażanej metafizycznej koncepcji coincidentia oppositorum, może lepiej zrozumieć nie tylko swoich przodków, ale także siebie i swoje miejsce w Kosmosie ${ }^{22}$.

Najlepszym dowodem prawdziwości tezy o niesłabnącej atrakcyjności formuły coincidentia oppositorum jest potrzeba miłości. „W gruncie rzeczy - zauważa Eliade - można mówić o «androgynizacji» człowieka przez miłość, gdyż w miłości każda płeć nabiera «cech» płci odmiennej, (np. wdzięk, poddanie się i oddanie - cechy, jakich nabiera zakochany mężczyzna)" ${ }^{23}$. Miłosny wątek zagadnienia może stanowić źródło wielu nieporozumień, uproszczeń czy wręcz wulgaryzacji formuły coincidentia oppositorum. Postrzeganie wszystkiego jedynie w kategoriach zmysłowych, anatomicznych i fizjologicznych, wyłącznie jako możliwość całkowitego spełnienia w sferze seksualnej, zarówno jako mężczyzny, jak i jako kobiety, nie tylko nie oddaje pełni znaczeń zawartych w omawianej formule, ale wręcz wskazuje na chorobliwą sytuację kultury, w ramach której takie wulgarne interpretacje się pojawiają. Kiedy umysł nie jest już w stanie pojąć głębszego, metafizycznego znaczenia symboli, zaczyna coraz bardziej je wulgaryzować ${ }^{24}$.

$20 \quad$ Por. M. Eliade, Mefistofeles i androgyn, op. cit., s. 125.

21 „Środki mogą być jak najprostsze, niekiedy dziecinne i wręcz dziwaczne; dochodzi się wtedy do scalenia przeciwieństw w konkretnym, bezpośrednim znaczeniu tego słowa i osiąga sposób istnienia, który nie jest już właściwy kondycji ludzkiej, ale też jeszcze nie jest nadludzkim sposobem istnienia”. Ibidem, s. 122.

22 „Jednym z największych odkryć ducha ludzkiego było naiwne przeczucie dnia, w którym dzięki pewnym symbolom religijnym człowiek odgadł, że biegunowości i antagonizmy mogą być połączone ze sobą i zintegrowane w jedną całość”. Ibidem, s. 217.

23 Ibidem, s. 446.

24 M. Eliade, Mefistofeles $i$ androgyn, op. cit., s. 102-103. 
Mircea Eliade zatytułował jedną ze swoich książek Mefistofeles $i$ androgyn ${ }^{25}$. W angielskim przekładzie tytuł brzmi: The Two and the One, i wprost nawiązuje do zagadnienia zbieżności przeciwieństw i androgynii: „Dwa i Jedno”, dwoje ludzi w jednym człowieczeństwie. Podobne stwierdzenie znajdujemy w Biblii, kiedy Chrystus mówi: „A tak już nie są dwoje, lecz jedno ciało” (Mt 19, 6).

Termin ,androgyn” pochodzi z języka greckiego i jest połączeniem dwóch słów: andrós - mężczyzna oraz gyné - kobieta. Oznacza dosłownie mężczyzno-kobietę. Zjawisko androgynii, jak uważa Eliade, wskazuje na doskonałość stanu pierwotnego, nieuwarunkowanego, dlatego nie jest zarezerwowane jedynie dla istot najwyższych ${ }^{26}$. Antyczne społeczności były przekonane, iż ziemska kondycja człowieka (męska i żeńska) nie odzwierciedla pierwotnego obrazu androgynicznej istoty ludzkiej. Starożytni sądzili, że człowiekiem rządzą te same prawą, którym podlega cały Kosmos. Człowiek stanowi część Wszechświata, natomiast prarodzica istoty ludzkiej łączono z ubóstwionym elementem Kosmosu, głównie Ziemią. Wzorem pierwotnej materii kosmicznej, człowiek posiadał kondycję androgyna, lecz utracił ją w wyniku pewnego, szczególnego wydarzenia, które spowodowało podzielenie jego osoby na dwa osobniki - mężczyznę i kobietę. Mit boski staje się modelem dla religijnych przeżyć człowieka. Zgodnie z licznymi tradycjami mityczni przodkowie ludzkości byli obojnakami. Motyw „pierwotnych par” pojawia się w mitologii dopiero później. Eliade twierdzi wprawdzie, iż występowanie obojga płci u pierwotnego człowieka jest kultywowane $\mathrm{w}$ tradycji społeczeństw pierwotnych, ale w swych badaniach odwołuje się głównie do przykładów zaczerpniętych od Platona i gnostyków ${ }^{27}$.

Platon w dialogu Uczta przedstawia Arystofanesa jako autora mitu pierwszego człowieka, który był istotą dwupłciową: „Obojnakowa płeć istnieje wtedy, a imię jej i postać złożone były z obu pierwiastków: męskiego i żeńskiego. (...) Otóż cała postać człowieka każdego była krągła, piersi i plecy miała naokoło, miała też cztery ręce i nogi w tej samej ilości, i dwie twarze na okrągłej, walcowatej szyi, twarze zgoła do siebie podobne. Obie patrzyły w strony przeciwne z powierzchni jednej głowy. Czworo było uszu, dwie okolice wstydliwe i tam dalej, jak sobie to każdy łatwo podług tego sam wyobrazić potrafi"28. Androgyniczne postacie, o których pisze Platon, chciały uzyskać boskie przywileje i zaczęly wznosić schody do nieba. Bogowie, karząc ich zuchwałość, przecięli

25 Praca Mircei Eliadego, Mefistofeles $i$ androgyn, została przetłumaczona na język polski na podstawie oryginału w języku francuskim: Méphistophéles et l'androgyne, Gallimard, Paris 1981 (wyd. I: 1962). Wydanie angielskie opatrzono innym tytułem: The Two and the One, Harvill Press, London 1965.

26 M. Eliade, Mity, sny i misteria, tł. K. Kocjan, Warszawa 1994, s. 214.

27 Zob. M. Eliade, Traktat o historii religii, op. cit., s. 444.

28 Platon, Dialogi, t. II, tł. W. Witwicki, Kęty 1999, s. 53. 
każdego androgyna na połowę, co zdecydowanie osłabiło ich siłę oraz odniosło ten pozytywny skutek, że zwiększyło populację ludzi na ziemi. Pomysł bogów okazał się nie do końca szczęśliwy, albowiem obie połówki tak bardzo tęskniły za pierwotną jednością, że ginęły. Zeus postanowił zainterweniować i przeniósł organy płciowe z tylnej na przednią część ciała, umożliwiając ludzkim istotom przywracanie pierwotnego stanu całości w miłosnym zespoleniu ${ }^{29}$. Rozbicie androgyna jest więc odpowiedzialne za ciągle podejmowane przez mężczyzn i kobiety wysiłki na rzecz odzyskania pierwotnej całości ${ }^{30}$.

Dwupłciowość pierwszego człowieka byłaby wyrazem doskonałości oraz integracji całkowitej, na co wskazują przedstawienia pierwotnego człowieka jako postaci kuli. Kula była symbolem doskonałości oraz całkowitości. Eliade powołuje się tu na taoistyczną tradycję „tchnienia”, będącą również wcieleniem obu płci, które zróżnicowane tworzyły jajo, pojmowane jako ogromną jednię, $z$ którego to jaja wyodrębniły się niebo i ziemia ${ }^{31}$.

Uczony powołuje się na Szkota Eriugenę (810-877), który pod wpływem Grzegorza z Nyssy (ok. 335-395) głosił prawdę o podwójnym stworzeniu człowieka: „Jedno (stworzenie jest) na obraz Boży i nie pojmuje się tutaj ani (płci) męskiej ani żeńskiej, lecz samo powszechne i proste człowieczeństwo, najbardziej zbliżone do natury anielskiej, która to natury, zgodnie z tym, czego w sposób niebudzący wątpliwości naucza autorytet i prawdziwe badanie, nie posiada wcale płci. Drugie (stworzenie jest) natomiast dodane $z$ powodu przewidzianego grzechu natury (ludzkiej) i w tej (właśnie) kreacji została ustanowiona płeć”32.

Stan rajski człowieka, na początku stworzenia był dla człowieka źródłem szczęścia i racją szczególnej godności bytu ludzkiego, za którego sprawą człowiek przewyższał cały świat zmysłowy ${ }^{33}$. Natura ludzka odznaczała się wtedy wszechwiedzą i wszechmocą, która wynikała z doskonałego zespolenia z Wolą Stwórcy: realizowało się wszystko to, czego zapragnęła, gdyż pragnęła tylko tego, co jest zgodne z Wolą Bożą. Była wolna od wszelkich ograniczeń i od wszelkiej konieczności. Zawsze osiągała to, czego pragnęła, a tym było wyłącznie dobro. Była prosta i niezróżnicowana pod względem płci. Człowiek miał wprawdzie ciało, ale było ono niematerialne, duchowe. Człowiek jest czymś $29 \quad$ Ibidem, s, 53-55.

30 W. Doniger O'Flaherty, M. Eliade, hasło: Androgynes, [w:] The Encyclopedia of Religion, M. Eliade (red.), t. 1, New York - London 1987, s. 277.

31 M. Eliade, Traktat o historii religii, op. cit., s. 444; idem, Mefistofeles $i$ androgyn, op. cit., s. 128.

32 Jan Szkot Eriugena, Periphyseon, ks. IV, 817a, s. 107, cyt. za A. Kijewska, Eriugena, Warszawa 2005, s. 82.

33 Ibidem, s. 82. Por. studium: I. Dec, Transcendencja człowieka w przyrodzie, Wrocław 2011. 
lepszym niż płeć, jako że „mężczyzna” i „kobieta” nie są określeniami natury, ale jej rozczłonkowania z racji grzechu ${ }^{34}$. Eliade, postępując za Eriugeną, uważa, że rozdział płci to następstwo grzechu, ale skończy się ponownym scaleniem człowieka, po czym nastąpi eschatologiczne połączenie kręgu ziemskiego z Rajem. I dodaje, że w Chrystusie mamy przykład antycypowania tej ostatecznej integracji. Powołując się na Eriugenę i Maksyma Wyznawcę (580-662) pisze, że Chrystus połączył w swej naturze obie płcie, ponieważ zmartwychwstając nie był już „ani mężczyzną, ani kobietą, choć narodził się i zmarł jako osobnik płci męskiej”35. To będzie także udziałem człowieka po zmartwychwstaniu, nie będzie ani mężczyzny ani kobiety, będzie po prostu człowiek.

Niektóre komentarze rabinackie wskazują na to, że również Adam był stworzony jako obojnak. Tekst midraszu Bereszit rabba stwierdza: „Adam i Ewa zostali stworzeni odwróceni plecami do siebie obejmując się ramionami; wtedy Bóg rozdzielił ich, rozcinając na dwoje jednym uderzeniem siekiery" ${ }^{6}$.

Pojawienie się Ewy oznaczałoby podzielenie pierwotnego obojnaka na istotę męską i żeńską ${ }^{37}$. Pochodzenie Ewy od Adama jest przyczyną tego, że odtąd mężczyźni i kobiety będą dążyli, podobnie jak u Platona, do urzeczywistniania pierwotnej jedni w fizycznym połączeniu $(\operatorname{Rdz} 2,24)^{38}$.

Mit androgynii boskiej oraz przodka obojnaka pełni wzorcową rolę dla licznych obrzędów zbiorowych: orgii, androgynizacji inicjacyjnej, technik mistycznych. Obrzędy te łączy chęć periodycznego reaktualizowania początkowego stanu, odbieranego jako idealny stan ludzkości ${ }^{39}$.

Mircea Eliade uważał, że mit androgynii mógł być wzorcowy także dla mistyki. Wschodni mędrcy i asceci, poprzez techniki i metody kontemplacji zmierzają do absolutnej transcendencji wszelkich przymiotów każdej natury. Pragną usunąć ze swego doświadczenia oraz świadomości wszelką „krańcowość”, czyli usiłują dojść do stanu neutralności i doskonałej obojętności, bycia niezależnym, nieczułym na przyjemność i ból. Tego rodzaju pokonywanie krańcowości przy zastosowaniu ascezy i kontemplacji zmierza także do coincidentia oppositorum. Świadomość uwalnia się wówczas od konfliktów, natomiast zespoły przeciwieństw, np. cierpienie i radość, zimno i ciepło, stają się nieobecne w jego doświadczeniu. Jednocześnie dokonuje się proces totalizacji - analogicznie do zjawiska totalizacji przeciwieństw w bóstwie. Doskonałość jest osiągalna

\footnotetext{
A. Kijewska, Eriugena, op. cit., s. 84.

M. Eliade, Mefistofeles $i$ androgyn, op. cit., s. 107.

Ibidem; idem, Traktat o historii religii, op. cit., s. 444.

Ibidem.

W. Doniger O'Flaherty, M. Eliade, Hasło: Androgynes, op. cit., s. 277.

M. Eliade, Traktat o historii religii, op. cit., s. 445.
} 
jedynie na drodze totalizacji przeciwieństw. Neofita na wstępie zmierza do „kosmizacji” swojego doświadczenia, aby upodobnić je do rytmów obecnych we wszechświecie. Po osiągnięciu „kosmizacji” podejmuje wysiłek odtwarzania w sobie pierwotnej jedności. Jedność nie oznacza chaosu poprzedzającego stworzenie, lecz niezróżnicowany, wszystko pochłaniający byt ${ }^{40}$.

Świat archaiczny traktuje ,zaczynanie” czegoś jako stwarzanie, czyli wykorzystanie świętych mocy. Wynika z tego podobieństwo strukturalne, jakie można dostrzec w odniesieniu do mitu pierwotnego androgyna, protoplasty ludzkości oraz mitów kosmogonicznych. Obydwa mity wskazują na początkową, jednolitą pełnię, która w trakcie stworzenia została podzielona dając początek światu i ludzkości ${ }^{41}$. Androgyn był jako pierwszy i będzie na końcu czasów. To dzięki Chrystusowi człowiek na powrót stanie się androgynem, podobnym do aniołów. Według wielu historyków religii i teologów sakrament małżeństwa jest próbą przywrócenia człowiekowi anielskiego obrazu: „A tak już nie są dwoje, lecz jedno" (Mt 19, 6).

\section{Próba adaptacji zasady coincidentia oppositorum do teologii biblijnej}

Teologia to odczytywanie rzeczywistości w świetle Objawienia, czyli Pisma Świętego i Tradycji Kościoła. Właściwie nie ma tu miejsca dla mitycznej interpretacji rzeczywistości, ale można zawsze szukać pewnych analogii i podobieństw.

W teologii małżenstwa kluczowym tekstem jest opis stworzenie człowieka zamieszczony w Księdze Rodzaju: „Potem Bóg rzekł: «Nie jest dobrze, żeby mężczyzna był sam; uczynię mu zatem odpowiednią dla niego pomoc». Ulepiwszy z gleby wszelkie zwierzęta ziemne i wszelkie ptaki powietrzne, Bóg przyprowadził je do mężczyzny, aby przekonać się, jaką on da im nazwę. Każde jednak zwierzę, które określił mężczyzna, otrzymało nazwę «istota żywa». I tak mężczyzna dał nazwy wszelkiemu bydłu, ptakom powietrznym i wszelkiemu zwierzęciu polnemu, ale nie znalazła się pomoc odpowiednia dla mężczyzny. Wtedy to Bóg sprawił, że mężczyzna pogrążył się w głębokim śnie, i gdy spał, wyjął jedno z jego żeber, a miejsce to zapełnił ciałem. Po czym Bóg z żebra, które wyjął z mężczyzny, zbudował niewiastę. A gdy ją przyprowadził do mężczyzny, mężczyzna powiedział: «Ta dopiero jest kością z moich kości i ciałem z mego ciała! Ta będzie się zwała niewiastą (iszsza), bo ta z mężczyzny (isz) została

$40 \quad$ Idem, Traktat o historii religii, op. cit., s. 441; idem, Mefistofeles $i$ androgyn, op. cit., s. 138. Por. A. Lelito, Człowiek - animal mythicum w ujęciu Mircei Eliadego, Tarnów 2008, s. $175-179$.

$41 \quad$ M. Eliade, Mefistofeles $i$ androgyn, op. cit., s. 138. 
wzięta». Dlatego to mężczyzna opuszcza ojca swego i matkę swoją i łączy się ze swą żoną tak ściśle, że stają się jednym ciałem" ( $\mathrm{Rdz} 2,18-24)$.

Faktem znanym $z$ doświadczenia jest niezwykle silne dążenie (,jak śmierć potężna jest miłość" - Pnp 8, 6), skłaniające dwie osoby odmiennej płci do tworzenia, w związku małżeńskim, jednej istoty („,jednego ciała”), dążenie tak silne, że odsuwa na drugi plan, albo wprost każe zapominać, związki na pozór o wiele bardziej głębokie, te, które istnieją między dzieckiem a rodzicami. Mężczyzna i kobieta są od zarania swego stworzenia wprost czymś jednym z natury.

Zwierzęta, nasi starsi bracia o ontologicznym porządku stworzenia, odgrywają służebną rolę w stosunku do człowieka. Człowiek włącza je w całokształt swojego życia i ma nad nimi władzę. Jednakże zwierzę nie może stać się istotą, która powie do człowieka „ty”, nie może stać się jego drugim „ja”. Kobieta jest tej samej natury, co mężczyzna, a więc jest mu równa w godności. Trudno przetłumaczyć pokrewieństwo dwóch słów hebrajskich - isz i iszsza. Instynkt, który popycha mężczyznę i kobietę do zespolenia się w jedności, wypływa z najgłębszych pokładów istoty ludzkiej. Szczególnie godne uwagi jest pełne zachwytu uniesienie, zawarte $\mathrm{w}$ słowach wypowiedzianych przez mężczyznę: powtarza on trzy razy zaimek „ta”: „ta jest kością...”, „ta będzie się zwała...”, „bo ta z mężczyzny, isz, została wzięta”. Akcent położony jest na ich wzajemne dopełnianie się, na przeznaczenie jednego dla drugiego. To wyjątkowa podwójności składników „jednego ciała”: tylko w parze, bez zewnętrznych ingerencji, człowiek rozwija się w pełni. Chrystus w polemice z faryzeuszami przedstawił tę pierwszą parę ludzką jako wciąż aktualny ideał, ponieważ właśnie jako para złożona z mężczyzny i kobiety i do tego nierozerwalna - była ona zamierzona i stworzona przez Boga (Mk 10, 2-12).

Udręka, jaka ogarnia człowieka z powodu samotności, kiedy nie jest on w stanie urzeczywistnić związku z drugą osobą, jest jedną z przyczyn powstawania nienormalnych miłości, nienaturalnych zachowań seksualnych, buntów przeciw zasadom życia społecznego, skłonności do narkotyków, wzrostu przestępstw kryminalnych i politycznego terroru. Patologia umysłowa rodzi się z braku zdolności do nawiązywania stosunków społecznych: strach, nieufność, brak szacunku dla siebie i dla innych są źródłem wyizolowania się i cierpienia. A cierpieniem jest utrata drogiej osoby, zerwaniem więzi uczuciowej, opuszczeniem przez kogoś, kto wydawał się niezastąpiony.

Siłą, która łączy mężczyznę i kobietę jest miłość: ta miłość z początku mniej jest zdolna do dawania i raczej nastawiona jest na przyjmowanie. Stopniowo staje się bardziej stateczna i ze wzajemnością w dawaniu i przyjmowaniu. Gdy osiąga pełną dojrzałość nastawiona jest na dawanie bez przyjmowania wynagrodzenia, a jeśli już, to na zasadzie wzajemności. 
W obrębie miłości małżeńskiej szczególnie ważne jest poznanie podświadomych bodźców, leżących u podstaw jedności, która tworzy się między dwiema osobami odmiennej płci. Dwie osoby, które nigdy się przedtem nie znały, „rozpoznają się” jako przeznaczone jedna dla drugiej, nie mogąc sobie wprost uświadomić powodów, które nakłaniają je do połączenia swoich dróg życia na zawsze.

Zatem szczególną cechą charakterystyczną miłości małżeńskiej jest jej „specyficzność”, w takim sensie, że w parze małżeńskiej są zaspokajane pewne potrzeby, które są właściwe obu osobom i które, ze względu na swą wyjątkowość, nie mogą zostać zaspokojone przez inne osoby. Tym, co łączy małżonków, jest możliwość wzajemnego „dopełniania się”, w takim sensie, że jedna osoba dopełnia drugą i że udziela jej tego rodzaju właściwej pomocy, której konkretnie ona potrzebuje. Warunek powodzenia małżeństwa leży w uświadomieniu sobie i określeniu potrzeb, które łączą dwie osoby, oraz w dążeniu, by każda z nich zaspokajała je mając na względzie korzyść drugiej strony. Trudność polega jednak na tym, że takie potrzeby nie ujawniają się same nigdy albo prawie nigdy na poziomie świadomości, ale tętnią w głębiach nieświadomego życia psychicznego. Dlatego wzajemny pociąg odmiennych płci ku sobie jest „niepowstrzymalny”, niewytłumaczalny, niepojęty. Działa on w sposób tajemniczy i tylko obserwacja specjalisty może częściowo rzucić światło na niektóre jego aspekty i przedłożyć je świadomej refleksji tej pary ludzi. Prawdą jest natomiast, że oboje małżonkowie „czują” lub „wiedzą”, nie mogąc sobie tego wytłumaczyć, że nie potrafią już żyć jedno bez drugiego i że tylko w ten sposób będą mogli prawdziwie urzeczywistnić swoje osobowości i tym samym spełnić swoje marzenia rodzinne. To spostrzeżenie dodaje pewności i nadziei na przyszłość, chociaż brak jest tutaj jakiegokolwiek elementu obiektywnego wartościowania. Wzajemne zainteresowanie, rodzące się z tego spostrzeżenia, przeistacza się w fizyczny pociąg i umożliwia, w związku małżeńskim również i intymne zjednoczenie, w którym także i ciała wspólnie dostrajają się do siebie, dostarczając sobie nawzajem zmysłowych doznań i ustanawiając tę „wspólnotę” wzajemnych odczuć, leżących u podstaw małżeńskiej harmonii.

„Dwoje, którzy stają się jednym” jest prawem miłości małżeńskiej. Chodzi tu jednakże o jedność, w której żadna z dwu osób nie zatraca swej tożsamości, ale spaja ją z tożsamością drugiej osoby, „daje siebie, nic nie tracąc”. Jest to dawanie siebie i jednoczenie się bez zatracania osobowości, pozostawanie razem $z$ sobą nie tracąc możliwości, by być samym.

U podstaw miłości małżeńskiej, jeszcze bardziej niż w stosunkach społecznych, leży uznanie osoby jako istoty samodzielnej i autonomicznej, zdolnej do nawiązania pogłębionych relacji psychicznych, będącej źródłem i sprawcą 
czynów wolnych i odpowiedzialnych. Takie uznanie osoby zakłada wolność, odpowiedzialność, równość.

Wzajemny szacunek jest warunkiem trwałego istnienia związku zawartego z miłości: szacunek, który rodzi się z dostrzegania „wartości” obecnych w drugiej osobie, nie jako osobie abstrakcyjnej, ale jako osobie „szczególnej”, jako „tej właśnie osobie, a nie innej”, a zatem niezastąpionej. Taki jest oto podstawowy warunek wierności: być związanym z nim, czy z nią, umieć podążać razem ku pełniejszemu urzeczywistnianiu jedności pary, jako pary małżeńskiej, we wspólnocie wymiany nie tylko emocjonalnej, ale także i wymiany myśli, wspólnocie społecznego otwarcia się, rzeczywistego i twórczego wchodzenia w społeczeństwo.

Pismo Święte i psychologia są zgodne w poglądzie, że kobieta nie jest „przedmiotem uzupełniającym” mężczyznę w związkach z Bogiem i w stosunkach społecznych. Kobieta jest przecież stworzeniem pod licznymi względami (fizycznymi, biologicznymi, psychologicznymi, umysłowymi, funkcjonalnymi i zwyczajowymi) różniącym się od mężczyzny (na co zwraca nam uwagę Pismo Święte w słowach: „Bóg stworzył mężczyznę i niewiastę”, Rdz 1, 27). Mężczyzna różni się od kobiety. Oboje - on i ona - stanowią odrębne osobowości i pod wieloma względami są samowystarczalne. Ta pełnia osobowości jest wyraźna w stosunkach z Bogiem. Ani mężczyzna nie będzie zbawiony za sprawą kobiety, ani kobieta za sprawą mężczyzny, ale oboje będą zbawieni za sprawą Chrystusa. Nie istnieje jedna religia dla mężczyzny, a inna dla kobiety; nie jest możliwy, w stosunkach z Bogiem, jeden związek typu męskiego i drugi typu żeńskiego. To stwierdzenie zostało podkreślone w takich oto słowach przez św. Pawła: „Nie ma już niewolnika ani człowieka wolnego, nie ma już mężczyzny ani kobiety, wszyscy bowiem jesteście kimś jednym w Chrystusie Jezusie" (Ga 3, 28). Mężczyzna i kobieta są w rzeczywistości obdarzeni takimi samymi wartościami etycznymi.

Równowaga życia utrzymuje się dzięki związkowi mężczyzny i kobiety, i to bardziej niż dzięki rodzinie i społeczności. Nie do pomyślenia byłby bowiem świat złożony z samych kobiet, tak samo jak nie do pomyślenia byłby świat zamieszkiwany jedynie przez mężczyzn. Nie istnieje jednak zależność kobiety w stosunku do mężczyzny. Mężczyzna i kobieta są - jak to się mówi w języku geometrycznym - częściami „stycznymi”, to jest składnikami jednej całości. Należy zatem podkreślić, że związki między mężczyzną - mężem a kobietą - żoną są związkami styczności, i to o charakterze dynamicznym, a nie statycznym. Na przestrzeni ludzkiego życia lub, na mniejszą skalę, na przestrzeni krótszego czasu wartości tego rodzaju „styczności” przemieszczają się ustawicznie, i bez dyskryminacji którejkolwiek ze stron, na korzyść raz mężczyzny, raz kobiety, przy ciągłej zmienności zależnie od tej wymiany dóbr, jaka się dokonuje między 
mężczyzną, a kobietą. Ta zmienność może być uważana za „napędową siłę życia” istniejącą między dwojgiem ludzi i utworzoną z wzajemnej wymiany dóbr, która będzie przyczyniać się do rozwoju życia w takim stopniu, w jakim, zwiększy ona w czasie swoją częstotliwość.

Tajemnica pary małżeńskiej jest bardzo złożona, ponieważ stanowi ją pełnia odrębnych osób, a zarazem ich potrzeba wzajemnego dopełniania się, ich podobieństwo i równocześnie ich odmienność. W perspektywie biblijnej kobieta ukazuje się jako odpowiednia pomoc dla mężczyzny, podobna do niego i równa mu; ale także i mężczyzna, według współczesnych poglądów, jawi się nam jako odpowiednia pomoc dla kobiety, podobny do niej i równy jej. Kobieta zachowuje przeto swoją osobowość całkowicie niezależną od osobowości mężczyzny, co oznacza, że nie może ona być uważana za „część” równą, dopełniającą albo podporządkowaną mężczyźnie, a tym bardziej nie może być „odbiciem”, obrazem lustrzanym mężczyzny. Mężczyzna nigdy nie będzie mógł, w dosłownym tego słowa znaczeniu, rozpoznać siebie samego - ani w całości, ani w części - w osobie zupełnie różniącej się od niego, jaką jest właśnie kobieta w swojej naturze.

Ponieważ wobec Boga na kobiecie spoczywają takie same odpowiedzialności i obowiązki, jak na mężczyźnie, powinna być ona oceniana przez mężczyznę dokładnie tak samo, jak on ocenia siebie samego. Nie będzie zatem prawdą, że mąż rozpoznaje siebie w swojej żonie lub odwrotnie, że żona rozpoznaje siebie w swoim mężu. Osobowości odróżniające się od siebie w wyraźnie odmienny sposób, tym mocniej czują się przyciągane jedna przez drugą, im bardziej jedna nie jest identyczna $z$ drugą, lub raczej, im mniej jedna upodabnia się do drugiej. Powtarza się tu ta sama znana reakcja, jaka zachodzi między dwoma biegunami (dodatnim i ujemnym biegunem pola magnetycznego), przyciągającymi się tym mocniej, im różnica między nimi (w tym przypadku napięcie) jest większa ilościowo i w konkretnych wartościach. Różnica uwidacznia się między sumą cech męskich i sumą cech kobiecych. Te wartości (natury psychicznej, duchowej, fizycznej) - jeżeli tylko wzbudzają wzajemne zainteresowanie - ułatwiają przeskok iskry miłości między dwiema osobami. Miłość jest zatem czymś tak nowym i nieprzewidzianym, może być uznana za cud, który nie przypadek, ale jedynie Bóg może sprawić. Tylko On mógł stworzyć i doprowadzić do spotkania dwie istoty pełne, a równocześnie dopełniające się, które - razem - zapoczątkowują niezwykły i niepowtarzalny związek. Kiedy przychodzi miłość, to tak jakby przyszedł sam Bóg. Tylko w Bogu człowiek rozpoznaje siebie samego, ponieważ tylko w Nim odkrywa motywy, które sprawiły, iż został stworzony, i cele, ku którym został skierowany. Człowiek, który ma problem z wiarą w Boga nie może do końca wiedzieć czym jest miłość, bo „Bóg jest miłością” (1 J 4, 8.16). 
Słowa kluczowe: Mircea Eliade, małzeństwo, coincidentia oppositorum, androgyn.

\section{Bibliografia:}

1. Adamski F., Rodzina między sacrum a profanum, Poznań 1987.

2. Dec I., Transcendencja czlowieka w przyrodzie, Wrocław 2011.

3. Doniger O'Flaherty W., Eliade M., hasło: Androgynes, [w:] The Encyclopedia of Religion, M. Eliade (red.), t. 1, New York - London 1987.

4. Eliade M., Moje życie. Fragmenty dziennika 1941-1985, tł. I. Kania, Warszawa 2001.

5. Eliade M., Historia wierzeń i idei religijnych, t. I, tł. S. Tokarski, Warszawa 1988.

6. Eliade M., Historia wierzen i idei religijnych. Od Mahometa do wieku reform, t. III, tł. A. Kuryś, Warszawa 2008.

7. Eliade M., Mity, sny i misteria, tł. K. Kocjan, Warszawa 1994.

8. Eliade M., Mefistofeles $i$ androgyn, tł. B. Kupis, Warszawa 1994/

9. Eliade M., Sacrum i profanum. O istocie religijności, tł. R. Reszke, Warszawa 1996.

10. Eliade M., Traktat o historii religii, tł. J. Wierusz Kowalski, Warszawa 2000.

11. Eliade M., W poszukiwaniu historii i znaczenia religii, tł. A. Grzybek, Warszawa 1997.

12. Głażewska E., Androgynia - model człowieka XXI wieku, „Annales Universitatis Mariae Curie-Skłodowska", Lublin - Polonia, t. XXVI, 2, 2001.

13. Goldsmith B., Geniusz i obsesja. Wewnętrzny świat Marii Curie, Wrocław 2006.

14. Jan Szkot Eriugena, Periphyseon, ks. IV.

15. Kijewska A., Eriugena, Warszawa 2005.

16. Lelito A., Człowiek - animal mythicum w ujęciu Mircei Eliadego, Tarnów 2008.

17. Małachowski A., Kobiety w matematyce, [w:] Zyjemy dla Pana: księga pamiątkowa dedykowana S. Profesor Ewie Józefie Jezierskiej OSU w siedemdziesiata rocznicę urodzin, M. Rosik (red.), Wrocław 2005.

18. Małachowski A., Objawiajace się sacrum, Wrocław 1999.

19. Mikołaj z Kuzy, O oświeconej niewiedzy, Kraków 1997.

20. Moir A., Jessel D., Płeć mózgu. O prawdziwej różnicy między mężczyzna a kobieta, tł. N. Kancewicz-Hoffman, Warszawa 1993.

21. Platon, Dialogi, t. II, tł. W. Witwicki, Kęty 1999.

22. Rega A., Człowiek w świecie symboli. Antropologia filozoficzna Mircei Eliadego, Kraków 2001. 